\title{
Citrus sinensis Flower Oil
}

National Cancer Institute

\section{Source}

National Cancer Institute. Citrus sinensis Flower Oil. NCI Thesaurus. Code C107292.

The essential oil from the flower of Citrus sinensis. Orange blossom oil is used primarily for aromatherapy. 